\title{
Assessing the Glass Ceiling Effect for Women in Tourism and Hospitality
}

\author{
Ibrahim Bazazo ${ }^{1}$, Mohammed Abdullah Nasseef ${ }^{2}$, Batool Mukattesh $^{1}$, Duha Kastero ${ }^{1} \&$ Mohammad Al-Hallaq ${ }^{1}$ \\ ${ }^{1}$ Department of Tourism Management, Faculty of Tourism and Hospitality, The University of Jordan, Aqaba, Jordan \\ 2 Department of Business Administration, Faculty of Economics and Administration, King Abdulaziz University, \\ Jeddah, Saudi Arabia \\ Correspondence: Ibrahim Bazazo, Department of Tourism Management, Faculty of Tourism and Hospitality, The \\ University of Jordan, Aqaba, Jordan. Tel: 962-3-209-0450. E-mail: i.bazazo@ju.edu.jo
}

Received: June 15, 2017

Accepted: June 22, 2017

Online Published: June 27, 2017

doi:10.5430/jms.v8n3p51

URL: https://doi.org/10.5430/jms.v8n3p51

\begin{abstract}
The aim of this research is to explore the degree to which women face various barriers that prevent them as a worker in the tourism sector, in the city of Aqaba located in Jordan, from obtaining upper-level positions. These include internal business structural barriers, societal barriers, governmental barriers, situational barriers, and personal barriers. A total of 200 questionnaire containing 27 items was used to collect information from women who are working in the industries of tourism and hospitality. Results of the current study revealed that all the above barriers are applied to moderate and low levels in which the range of the mean score are 2.16-3.35 out of 4. This study shall provide important feedback to decision-makers to enhance and empower the women further in the tourism and hospitality disciplines specifically in Aqaba city.
\end{abstract}

Keywords: glass ceiling effect, tourism industry, Aqaba, Jordan

\section{Introduction}

Tourism sector plays an important role in the Jordanian economy growth, attract investment, finds many job opportunities and enhance foreign currency entry to the market. Tourism sector witnessing a rapid investments activates to meet the demands of increasing numbers of tourists starting from the establishment of several investment projects for both hotels restaurants, recreational activities, conference centers, transportation and tourism services offices and other rehabilitation of archaeological and heritage sites in the Kingdom. During the past few years, Jordan has attracted foreign investment and increased the volume of internal investment due to the good planning and reform policies and legislation, through a series of successful steps to facilitate investment fields in Jordan and other factors which included the Jordan site, its distinctive heritage, its rich cultural, security and stability, moderate climate and nature, thriving business environment, the holy sites, adequate facilities and services for recreation. In addition to the continued interest in the maintaining and modernizing the infrastructure, the provision of services for restaurants and hotels aims to the highest international standards (Ajlouni \& Murar, 2012).

Among the most important forms of increasing women's participation in public life and increase their participation in the Jordanian labor market, where women entered in all sectors, including the tourism sector, which is considered. The tourism industry of the biggest international economic sectors in terms of size and importance, which has become a tourism largest shareholder industry in the global GDP, and in Jordan's tourism sector plays an important role in economic growth in Jordan and attract investment, as well as job creation and the introduction of hard currency, providing 42,000 tourism industry jobs. However, do not exceed the proportion of female participation in excess of $10 \%$, so it was a national strategy for tourism targets for the years 2011-2015 to raise the level of women's participation in the labor force 15\% (Al Zoubi \& Alkharoof, 2015).

Women play a key role in trade in Africa and will be essential to Africa's success in exploiting its trade potential. Women make a major contribution to trade in most African countries through their involvement in the production of tradable goods as cross-border traders and as managers and owners of firms involved in trade. In many countries in Africa, the majority of small farmers are women, and they produce crops such as maize, cassava, cotton, and rice that have enormous potential for increased trade between African countries and with the global market. Women are also 
involved in providing services across borders, such as education, health, and professional services, including accountancy and legal services. Hundreds of thousands of women cross borders in Africa every day to deliver goods from areas where they are relatively cheap to areas in which they are in shorter supply (Brenton et al., 2013).

Women's participation in economic activity brings benefits at both the micro and macro levels. In order to be employed, women need skills for which there is a demand in the labour market. It is normally expected that labour force participation rates increase with rising levels of education and training. Furthermore, in general, the more education one has, the greater one's individual income potential is (Majcher-Teleon \& Slimène, 2009). Women's labour force participation rate is very low in Jordan. The activity rate in 2009 was $73.9 \%$ for men and $23.3 \%$ for women according to the ILO. Although the enrolment of females' at all educational levels still lags behind that of males, the educational gender gap is too small to explain the gender gap in labour force participation. Women's skills and qualifications are not utilised to their full extent in Jordan (Majcher-Teleon \& Slimène, 2009).

The involvement of women in the workplace across the world in general and in South Africa in particular has been on the increase. Women are no longer employed to perform unskilled or semi-skilled jobs. Due to their access to education women are finding employment in all the functional areas of organizations and even as line managers. Whilst female representation at lower and middle management is on the increase, the trend is not the same at the senior management level. The under representation of women at senior management has been attributed to what several authors have termed the "glass ceiling". The concept of the "glass ceiling" emanated from corporate US where a commission termed the Glass Ceiling Commission was set up to investigate why the involvement of women in employment in the USA was not in proportion to their representation at senior management. The glass ceiling has been described as an invisible barrier akin to a concrete ceiling that is impenetrable and prevents the accession of women to senior levels of management. The way the glass ceiling manifests itself differs between countries and organizations. How the glass ceiling is managed will determine the success of an equitable workplace. This study will focus on the incidence and management of the glass ceiling in Durban organizations (Tohmé, 2001; Badarin \& Alqawasma, 2012; Kiaye \& Singh, 2013).

Modern society in the United States is often characterized as highly democratic, humanistic, and advanced. At the same time, arguments concerning the real equality of all people regardless of their race, gender, or social position, still persist. Arguments concerning the position of females in modern society are among the most contradictive. There are people who sincerely believe that women have managed to get an equal position in society compared to men and that women have real equal opportunities as men do However, there are other people with a totally different view on the position of women in modern society. According to them, the glass ceiling still remains an unsurpassable barrier women regularly face in their life (Clevenger \& Singh, 2013).

All women around the world in some stage of their life career need to break the "glass ceiling" to achieve their career goals. The ceiling is located above the lowest middle-level management positions and prevents women from attaining higher management positions. For Arabian women this ceiling is still a very hard challenge for them, although Arabian women achieve important steps in the field of leadership. For example Bahrain chamber of commerce grew from having no female members to 1785. In Saudi Arabia the chambers of commerce and industry are setting up female provision to support entrepreneurial development. In Jordan women are now graduating in high numbers from educational institutions and more women are entering the paid work force and taking up managerial roles but even though the number of women in leadership positions is relatively low in Jordan. The Glass ceiling term is extended to Glass cliff suggesting that women are more likely than men to find themselves on a glass cliff. Regardless of the terms, it is visible that women traditionally encounter a "glass ceiling" and men are more likely to be accelerated into management positions by means of a "glass escalator". Glass ceiling literature presents different theoretical perspectives, explaining the barriers that hinder career advancement for women. Some of them propose barriers such as attitudinal, behavioral and structural that hinders career advancement for many women. A perspective shows that the unequal career advancement of women was due to the attitudes of the more senior male colleagues who most frequently make decisions in an organization, such as: recruitment, selection, strategic planning and promotion outcomes, rather than any differences in the ability between male and female managers. Another perspective concentrates on structural or organizational constraints facing women. These can be viewed in straightforward practical terms at the level of the organization, such as a lack of child-care arrangements, networks or role models as well as encompassing domestic constraints. (Al-Manasra, 2013)

Despite the woman participation rate increase in the Jordanian labor market in general and the service sector and professions in particular with a margin of $1.5 \%$ between 2011 and 2012, but the number of working women in the services sector / tourism sector is lower as the number of females is 4455 employee compared with the number of 
males which reached 39022 employees in the tourism sector until June of 2012 where the largest number of them in the tourist restaurants 1623 employee, 1265 in tourist offices and hotels, then bazaars then tourism guidance and least in the dive and water sports centers (Ajlouni \& Murar, 2012). This study is trying to detect the reality of women's participation in this area and highlight the difficulties and obstacles that hinder their participation in the tourism-working field that provide good employment opportunities for them and review its relationship with gender differences, especially the difference of her working conditions. The study also broadens the base of information and knowledge about the tourism sector and its advantages to the local community, where the subject of "women in tourism in Jordan" suffers from a lack of research studies and this motivated us to work on the study.

\section{Literature Review}

The first barrier type is internal business structural barriers. The internal business structure reflects the attitudes and conditions of business as a whole. Glass ceilings in the business world are not an isolated feature of corporate architecture; rather, they are held in place by the attitudes of society at large. Exactly at what level this glass ceiling is apparent in an organization may differ; however, most observers agree that responsibility beyond the general management level has been difficult for women to achieve. According to the Women in U.S. Corporate Leadership report, their seven-year exercise in monitoring women's status has shown that women in corporate leadership are making steady but slow progress from a very low base. What are the strategies hospitality companies employ to identify high-potential women and help them develop, if any? A study in 1998 showed that the approaches women must take to rise to the executive level in the hospitality industry are not much different from strategies found in the corporate world in general (Clevenger \& Singh, 2013).

First studies on women entrepreneurs in Turkey have been published in the beginning of 1990s. While studies on SMEs (Small and Medium Enterprises) without a gender perspective concentrated on the issues related to the performance of the business, the early studies on women entrepreneurs focused primarily on the descriptive characteristics of the entrepreneur, particularly on their role attitudes in the enterprise and in the family, that is, their relations with their employees, business colleagues and with their family members. An important deficiency of these studies is that they draw on field studies based on small samples. Very few studies published in the 1990s intended to identify the problems faced by women entrepreneurs and to provide proposals and programs to facilitate and promote entrepreneurship among women. The recent studies, on the other hand, seem to lay more emphasis on the barriers women face while starting or running their enterprise (Ozar, 2007). The professional organizations active in the field of entrepreneurship do not publish data on gender basis which makes it impossible to make any kind of analysis with a gender perspective and regarding women's enterprises representative of the country or a specific region. The only study and data base available on women and men entrepreneurs of MSEs in Turkey representative of all MSEs in the urban areas of the country is carried out by the author of this report (Ozar, 2007).

A frequently mentioned reason for companies' hesitation to send female managers on international assignment is that foreigners' prejudice against women makes them ineffective as managers. Almost three-quarters of human resource managers from MNCs surveyed believed that foreigners are so prejudiced against females that women managers would not succeed on expatriate assignments. However, Hutchings et al. (2010) found that respondents reported numerous benefits of being female. Most frequently, they described the advantage of being highly visible. Both foreign and local clients were curious about them, wanted to meet them, and remembered them after the first encounter. Interest in women-led MSEs stems from recent development strategies concerned with the broad concept of women empowerment. With recent efforts by international and multilateral agencies, support for MSEs is generally acknowledged to improve women's economic situation. However this link is subject to certain conditions depending on the contexts where women-led enterprises are embedded (Hamdan et al., 2007).

A holistic approach to women economic empowerment goes beyond mere economic efficiency and growth of enterprises. Increasing women's control over resources is complemented with resisting dominant gendered ideology that reinforces social, economic and political manifestations of gender inequality. Following this approach, a gender analysis of women's position within economic practices is necessary to unveil the discrimination at both structural and institutional scales. Institutions of the household, community, market and state harbor legal and substantive discrimination in rights, entitlements that hinder women's equal access to and control over assets, resources and services (Hamdan et al., 2007). Women's empowerment in Lebanon can be measured at various social, economic, and political levels. National indicators on women's education and health rank among the highest in the region with high literacy rates especially among the young population, high life expectancy, low under five mortality and low maternal mortality. Civil and political indicators reveal high women participation in the NGO sector, but lower access to decision making and public positions. Women's economic participation tends to be low, characterized by gendered career choices, technical skills and early exit at marriage (Hamdan et al., 2007). 
Globally, there has been an unprecedented change occurring in the composition and participation of the workforce in the world economy. This change has been propelled by the active involvement of more women in the economy than before. According to the International Labor Organization, out of the world's 2.9 billion workers, 40 per cent were women. However, the increasing involvement of women in the work force is not synonymous with their representation at senior management levels. South Africa is mirroring the global trend with the increase in female participation in the workforce and senior management positions remaining the preserve of men. On the surface women are being accepted as part of the workforce, but their reception into senior management levels is stifled due to subtle forms of discrimination that present themselves in compensation, training and/or socialization networks. With the need to increase diversity in the workforce, a study conducted by Powell and Graves, indicated that the proportion of women holding lower and middle management positions had increased, concomitantly with their greater demand for equality in the work environment. However, the proportion of women reaching top management positions has remained relatively small pointing to the existence of discriminatory barriers to entry to senior management positions which has been termed the "glass ceiling" (Kiaye \& Singh, 2013).

Jordan is one of the Arabian countries with limited natural resources. Human resource is considered its strategic resource because the proportion of skilled workers in Jordan is among the highest in the region. Jordanian women served as a reserve labor force and were encouraged to work during the years of labor shortages when economic expansion and development plans were the highest on the government's priority list. In a 1988 study of women and work in Jordan found that cultural attitudes were not the major constraint in women's employment; the need and opportunity were more significant factors (Al-Manasra, 2013). Women and Tourism suffers from of the shortage of studies, however, it is worth reviewing some studies that have addressed topics related to women and work, though different aspects regarding her participation in work and work areas that she is involved in and the factors affect their work and the difficulties working women faced. Tourism is itself human-resource intensive due to the service nature of the industry. Further, one job in the core tourism industry creates additional (indirect) jobs in the tourism-related economy. For example: hypothetically in hotel segment; if there is an average of one employee for each hotel room, there are workers indirectly dependent on each person working in hotels, such as travel agency staff, guides, taxi and bus drivers, food and beverage suppliers, laundry workers, textile workers, gardeners, shop staff for souvenirs, airport employees and others. In general, tourism is linked to several other sectors, and can offers good opportunities to women to work in occupations directly or indirectly, where we can find in the women in these staffs (Ajlouni \& Murar, 2012):

1. Staff of the hotels, boarding houses, motels, tourist camps, touristic rest centers,

2. Staff of the touristic restaurants and cafeterias, food and beverage centers that provide meals and refreshments within touristic centers or destinations.

3. Staff of the Natural reserves, touristic destinations (in situ),

4. Staff of the Museums, touristic exhibition centers, touristic summer festivals.

5. Staff of the Airports, travel agencies, tourist guides, tours organizers, transportation companies and rent cars.

6. Staff of the tourism organization and institutes either governmental or non-governmental or private sector, tourism department in Universities as well as tourism information offices;

7. Staff of souvenirs and handcrafts shops and public touristic bazaars.

Staff of the recreation and relaxation centers and care body as well as sport tourism likes hiking.

Management researchers and policy makers recognized over two decades ago that a "glass ceiling" existed for women in management. The glass ceiling is often viewed as an invisible organizational barrier4 that is associated with gender or sex roles. The glass ceiling is an invisible barrier that exists within organizations, and evidences an invisible barrier in women's mobility to top decision making positions. Thus, the glass ceiling describes an organizational level beyond which female managers are not promoted even though they are as qualified as their male counterparts (Pollard, 2007).

It is visible after reviewing some previous studies that glass ceiling phenomenon aspects differ according to the western and eastern countries. For example, Storvik \& Schone (2008) study indicated that there are no organizational barriers in Norway's state bureaucracy that prevent women to arrive managerial positions, and female managers do not find any difficulty in combining both of work and family. The study dues the slow down women's movement into higher management position to the anticipated discrimination rather than lack of ambition or self-confidence. An investigation into the relative under representation of women in senior management positions in UK travel and tourism showed that the majority of respondents cited career breaks for child birth, child care and the pressures of 
combining work with family and personal commitments as the key issues. A substantial number pointed to male culture and the existence of an "old boys network" as well as the attitudes and behaviors of male managers in being significant explanatory factors. A Malaysian study showed that women middle managers face a glass ceiling in their working environment which inhibits the promotion of female managers and entails a barrier to the career development opportunities for women and entails that women do not have enough organizational support, such as: networking, mentoring and family friendly initiatives (Al-Manasra, 2013).

\section{Research Methodology}

The researcher used methodology that identifies the design; determine the population of the study and its sample by the search tool and method of preparation, indications of validity and reliability, as well as the process of data collection, analysis and statistical treatments used in the analysis .The design process for scientific studies depends on the nature of the problem and the goals expected to be achieved upon completion of addressing the problem on the other hand, and the researcher adopted the descriptive and analytical method in the completion of the current field study. The researcher used available references and sources for the preparation of the study theoretical framework, used questionnaire for data collection and statistical analysis to build the analysis hypothesis, the process of building questionnaire was based on the tourism management knowledge, as well as reviewing previous studies and research, conduct discussions with a large number of academics and tourism domain experts, in addition to the experience of the researcher in this area, the study tools were subjected to validity and reliability.

\subsection{Research Operational Definitions}

Adapted from Clevenger and Singh (2013); and Kiaye and Singh (2013), the current research considers five barriers women face that prevent them from obtaining upper-level positions. These includes internal business structural barriers, societal barriers, governmental barriers, situational barriers, and personal barriers; which were measured in the research questionnaire through four, six, four, seven and six items respectively.

\subsection{Research Hypotheses}

The study is hypothesized as follows:

H1: There is a significant difference among the barriers women face that prevent them from obtaining upper-level positions due to age.

$\mathrm{H} 2$ : There is a significant difference among the barriers women face that prevent them from obtaining upper-level positions due to education level.

H3: There is a significant difference among the barriers women face that prevent them from obtaining upper-level positions due to career level.

H4: There is a significant difference among the barriers women face that prevent them from obtaining upper-level positions due to work experience.

\subsection{Population and Sampling}

The target population of this study were female category, and adopted in this study Aqaba community Women's nonworker and the worker, especially the female element working in the tourism sector, 200 questionnaire distributed to women in Aqaba community which works in hotels, ASEZA and University of Jordan Aqaba branch, where they were distributed randomly, the questionnaire consists of two parts. The first section of the questionnaire contains the respondents' information such as name, educational level and job level and work experience and age. The second section includes questions to measure the independent and dependent variables on the basis of operational definitions, and reference standards in the questionnaire and questions were intended to rule on the existence of factors, if any, to prevent the development of women in the tourism sector, in addition to identifying the point of view of women in the tourism sector.

\section{Data Analysis and Results}

In order to explore the degree to which women face barriers that put off them from obtaining upper-level positions in tourism and hospitality sectors in Aqaba city, in which the items for these barriers have been measured using 5 -points Likert scale that varies between strongly disagree $=1$, and strongly agree $=5$; reliability and validity analyses were conducted, descriptive analysis was used to describe the characteristic of sample and the respondents to the questionnaires items. Descriptive statistical tools were used which represented by the standards of computational central trend such as standard deviations, frequency tables in addition to Pearson correlation coefficient whose value ranges between (-1-1) to measure the strength and direction of the relationship between the variables; regression analysis; and cronbach's alpha coefficient to measure the reliability and validity of the measurement tools. 


\subsection{Validity and Reliability}

Validity and reliability are two important measures to determine the quality and usefulness of the primary data. Validity is about accuracy and whether the instrument measures what it is intended to measure while reliability is about precision; it is used to check the consistency and stability of the questionnaire. Indeed, the researchers depended on scales and items that were previously developed and used by other researchers with similar interest. Also a draft of the questionnaire was formulated, and then it was reviewed by three academic lecturers -who have a sufficient knowledge and experience in this scope- to insure that each item is measuring what is intended to be measured, and to avoid the ambiguity and complexity in the phrasing of questions. The reliability of the instrument was measured by the Cronbach's alpha coefficient. Further, some scholars (e.g. Bagozzi \& Yi, 1988; Creswell, 2009) suggested that the values of all indicators or dimensional scales should be above the recommended value of 0.60. Table 1 represents the results of Cranach's alpha for the study barriers. Cronbach's alpha coefficients of all the tested variables are above 0.60 which suggesting the composite measure is reliable.

Table 1. The Cronbach's alpha coefficients of study variables

\begin{tabular}{lcc}
\hline Variables/ Barriers & Number of items & Cronbach alpha \\
\hline Internal Business Structural Barriers & 4 & 0.790 \\
\hline Societal Barriers & 6 & 0.682 \\
\hline Governmental Barriers & 4 & 0.633 \\
\hline Situational Barriers & 7 & 0.628 \\
\hline Personal Barriers & 6 & 0.838 \\
\hline
\end{tabular}

\subsection{Respondents Demographic Profile}

As indicated in Table 2, the demographic profile of the respondents for this study showed that they are all females, most of them between 18-less than 30 years old, the majorities hold bachelor degrees, and most of them work as first line/middle line managers, and have less than 10 years experiences.

Table 2. Description of the respondents' demographic profiles

\begin{tabular}{lccc}
\hline Category & Category & Frequency & Percentage\% \\
\hline Age & 18 years - less than 25 & 94 & 47.0 \\
\cline { 2 - 4 } & 25 years - less than 30 & 51 & 25.5 \\
\cline { 2 - 4 } & 30 years - less than 40 & 46 & 23.0 \\
\cline { 2 - 4 } & More than 40 years old & 9 & 4.5 \\
\hline Education level & Total & 200 & 100 \\
\cline { 2 - 4 } & High school & 11 & 5.5 \\
\cline { 2 - 4 } & Diploma & 32 & 16.0 \\
\cline { 2 - 4 } & Bachelor & 124 & 62.0 \\
\cline { 2 - 4 } & Master & 30 & 15.0 \\
\hline Career level & Doctorate & 3 & 1.5 \\
\cline { 2 - 4 } & Total & 200 & 100 \\
\cline { 2 - 4 } & Senior manager & 12 & 6.0 \\
\cline { 2 - 4 } & Middle manager & 60 & 30.0 \\
\cline { 2 - 4 } & First line manager & 69 & 34.5 \\
\cline { 2 - 4 } Work experience & Supervisors & 59 & 29.5 \\
\cline { 2 - 4 } & Total & 123 & 61.5 \\
\cline { 2 - 4 } & Less than 5 years & 60 & 30.0 \\
\cline { 2 - 4 } & 5 years - less than 10 & 17 & 100 \\
\cline { 2 - 4 } & More than 10 years & 200 & \\
\cline { 2 - 4 } & Total & & 100 \\
\hline
\end{tabular}




\subsection{Descriptive Analysis}

In order to describe the responses and thus the attitude of the respondents toward each question they were asked in the survey, the mean and the standard deviation were estimated. While the mean shows the central tendency of the data, the standard deviation measures the dispersion which offers an index of the spread or variability in the data (Pallant, 2005; Sekaran \& Bougie, 2013). In other words, a small standard deviation for a set of values reveals that these values are clustered closely about the mean or located close to it; a large standard deviation indicates the opposite. The level of each item was determined by the following formula: (highest point in Likert scale - lowest point in Likert scale) / the number of the levels used $=(5-1) / 5=0.80$, where $1-1.80$ reflected by "very low", 1.81-2.60 reflected by "low", 2.61-3.40 reflected by "moderate", 3.41-4.20 reflected by "high", and 4.21-5 reflected by "very high". Then the items were being ordered based on their means. Tables 3 and 4 show the results.

Table 3. Overall mean and standard deviation of the study's variables

\begin{tabular}{lcccc}
\hline Type of Variable/ Barrier & Mean & Standard Deviation & Level & Order \\
\hline Internal Business Structural Barriers & 3.2175 & 1.04073 & Moderate & 2 \\
\hline Societal Barriers & 3.1233 & 0.71735 & Moderate & 3 \\
\hline Governmental Barriers & 3.3563 & 0.83065 & Moderate & 1 \\
\hline Situational Barriers & 2.8714 & 0.59292 & Moderate & 4 \\
\hline Personal Barriers & 2.1608 & 0.92553 & Low & 5 \\
\hline
\end{tabular}

As presented in Table 3, data analysis results have shown that barriers face women from obtaining upper-level positions in Aqaba city in the industries of tourism and hospitality are applied to moderate and low levels in which the range of the mean score are 2.1608-3.3563. Table 4 demonstrates the mean, standard deviations, level, and order scores for items for each variable/standard.

Table 4. Mean and standard deviation of the study's variables

\begin{tabular}{lcccc}
\hline Internal Business Structural Barriers & Mean & SD & Level & Order \\
\hline Glass ceiling exists in my organization & 3.06 & 1.426 & Moderate & 4 \\
\hline There are fewer female managers than male managers in my organization & 3.49 & 1.264 & High & 1 \\
\hline $\begin{array}{l}\text { Women are not promoted to senior management positions at the same rate } \\
\text { as men in my organization }\end{array}$ & 3.19 & 1.364 & Moderate & 2 \\
\hline The "good old boys" network present in the organization & 3.15 & 1.254 & Moderate & 3 \\
\hline Societal Barriers & Mean & SD & Level & Order \\
\hline Society perceives women as have lower competence than men & 3.33 & 1.300 & Moderate & 3 \\
\hline Difference in gender-status beliefs negatively affects performance & 3.42 & 1.253 & High & 1 \\
\hline In Aqaba women hold lower status than men & 2.81 & 1.309 & Moderate & 5 \\
\hline $\begin{array}{l}\text { In Aqaba there is an abundant supply of qualified women waiting to move } \\
\text { into senior management positions }\end{array}$ & 3.10 & 1.248 & Moderate & 4 \\
\hline $\begin{array}{l}\text { Women are not taking advantages of the Job and promotion opportunities } \\
\text { available to them }\end{array}$ & 3.35 & 1.185 & Moderate & 2 \\
\hline $\begin{array}{l}\text { When compared to men, women lack the professional knowledge, skills, } \\
\text { and abilities to discover and compete favorably for professional } \\
\text { advancement }\end{array}$ & 2.74 & 1.266 & Moderate & 6 \\
\hline Governmental Barriers & & & & \\
\hline $\begin{array}{l}\text { Governments don't have policies which support motivates programs for } \\
\text { real success regardless gender }\end{array}$ & 3.24 & 1.211 & Moderate & 4 \\
\hline $\begin{array}{l}\text { There is lack of vigorous and consistent monitoring and law enforcement } \\
\text { of equal opportunity }\end{array}$ & 3.44 & 1.197 & High & 2 \\
\hline There is a weakness in the collection of employment-related data, such as & 3.29 & 1.200 & Moderate & 3 \\
\hline
\end{tabular}


gender and gender-related issues

\begin{tabular}{|c|c|c|c|c|}
\hline $\begin{array}{l}\text { There is inadequate reporting and publicizing of information relevant to } \\
\text { glass ceiling issues }\end{array}$ & 3.47 & 1.207 & High & 1 \\
\hline Situational Barriers & Mean & SD & Level & Order \\
\hline My work performance is fairly evaluated & 3.51 & 1.280 & High & 1 \\
\hline There are few career opportunities for me & 2.50 & 1.173 & Low & 7 \\
\hline There is gender discrimination in my workplace & 2.91 & 1.230 & Moderate & 3 \\
\hline I am not assigned to high visibility positions & 2.75 & 1.235 & Moderate & 4 \\
\hline I have to work extra hard to be recognized & 3.22 & 1.161 & Moderate & 2 \\
\hline I am not given support to balance multiple roles & 2.70 & 1.304 & Moderate & 5 \\
\hline I am not respected by male colleagues & 2.52 & 1.345 & Low & 6 \\
\hline Personal Barriers & Mean & SD & Level & Order \\
\hline I am not confident in my abilities & 1.87 & 1.208 & Low & 5 \\
\hline I am not emotionally suited to be a senior manager & 2.08 & 1.192 & Low & 3 \\
\hline I am not competitive & 2.02 & 1.201 & Low & 4 \\
\hline My subordinates don't have confidence in my leadership & 2.35 & 1.238 & Low & 1 \\
\hline I am not a high achiever & 2.31 & 1.242 & Low & 2 \\
\hline I didn't consider myself a leader & 2.35 & 1.384 & Low & 1 \\
\hline
\end{tabular}

\subsection{Hypotheses Testing Results}

Hypotheses $\mathrm{H} 1, \mathrm{H} 2, \mathrm{H} 3$, and $\mathrm{H} 4$ argued that there is a significant difference among the barriers women face that prevent them from obtaining upper-level positions due to age, educational level, career level, and work experience. ANOVA tests were employed to examine the four hypotheses. Results of T-test, shown in Tables 5-8, noting the abbreviations as IB: Internal Business Structural Barriers; SB: Societal Barriers; GB: Governmental Barriers; TB: Situational Barriers; and PB: Personal Barriers.

Table 5. ANOVA analysis of barriers women face that prevent them from obtaining upper-level positions due to age

\begin{tabular}{|c|c|c|c|c|c|c|}
\hline & & $\begin{array}{l}\text { Sum of } \\
\text { Squares }\end{array}$ & $\mathrm{df}$ & $\begin{array}{c}\text { Mean } \\
\text { Square }\end{array}$ & $\mathrm{F}$ & Sig. \\
\hline \multirow[t]{3}{*}{ IB } & $\begin{array}{l}\text { Between } \\
\text { Groups }\end{array}$ & 16.346 & 3 & 5.449 & 5.361 & .001 \\
\hline & Within Groups & 199.193 & 196 & 1.016 & & \\
\hline & Total & 215.539 & 199 & & & \\
\hline \multirow[t]{3}{*}{ SB } & $\begin{array}{l}\text { Between } \\
\text { Groups }\end{array}$ & 6.306 & 3 & 2.102 & 4.288 & .006 \\
\hline & Within Groups & 96.096 & 196 & .490 & & \\
\hline & Total & 102.402 & 199 & & & \\
\hline \multirow[t]{3}{*}{ GB } & $\begin{array}{l}\text { Between } \\
\text { Groups }\end{array}$ & 6.102 & 3 & 2.034 & 3.039 & .030 \\
\hline & Within Groups & 131.203 & 196 & .669 & & \\
\hline & Total & 137.305 & 199 & & & \\
\hline \multirow[t]{3}{*}{ TB } & $\begin{array}{l}\text { Between } \\
\text { Groups }\end{array}$ & 4.410 & 3 & 1.470 & 4.395 & .005 \\
\hline & Within Groups & 65.549 & 196 & .334 & & \\
\hline & Total & 69.959 & 199 & & & \\
\hline \multirow[t]{3}{*}{$\mathrm{PB}$} & $\begin{array}{l}\text { Between } \\
\text { Groups }\end{array}$ & 4.999 & 3 & 1.666 & 1.974 & .119 \\
\hline & Within Groups & 165.467 & 196 & .844 & & \\
\hline & Total & 170.465 & 199 & & & \\
\hline
\end{tabular}


Table 5 showed that there is a significant difference among four barriers women face that prevent them from obtaining upper-level positions due to age (i.e. among internal business structural barriers, societal barriers, governmental barriers, and situational barriers); whereas no significant difference found for personal barriers due to the moderator variable of age.

Table 6. ANOVA analysis of barriers women face that prevent them from obtaining upper-level positions due to educational level

\begin{tabular}{|c|c|c|c|c|c|c|}
\hline & & $\begin{array}{l}\text { Sum of } \\
\text { Squares }\end{array}$ & $\mathrm{df}$ & $\begin{array}{l}\text { Mean } \\
\text { Square }\end{array}$ & $\mathrm{F}$ & Sig. \\
\hline \multirow[t]{3}{*}{ IB } & $\begin{array}{l}\text { Between } \\
\text { Groups }\end{array}$ & 10.590 & 4 & 2.647 & 2.519 & .043 \\
\hline & Within Groups & 204.949 & 195 & 1.051 & & \\
\hline & Total & 215.539 & 199 & & & \\
\hline \multirow[t]{3}{*}{ SB } & $\begin{array}{l}\text { Between } \\
\text { Groups }\end{array}$ & 5.927 & 4 & 1.482 & 2.995 & .020 \\
\hline & Within Groups & 96.475 & 195 & .495 & & \\
\hline & Total & 102.402 & 199 & & & \\
\hline \multirow[t]{3}{*}{ GB } & $\begin{array}{l}\text { Between } \\
\text { Groups }\end{array}$ & 7.410 & 4 & 1.853 & 2.781 & .028 \\
\hline & Within Groups & 129.894 & 195 & .666 & & \\
\hline & Total & 137.305 & 199 & & & \\
\hline \multirow[t]{3}{*}{ TB } & $\begin{array}{l}\text { Between } \\
\text { Groups }\end{array}$ & 1.512 & 4 & .378 & 1.077 & .369 \\
\hline & Within Groups & 68.447 & 195 & .351 & & \\
\hline & Total & 69.959 & 199 & & & \\
\hline \multirow[t]{3}{*}{$\mathrm{PB}$} & $\begin{array}{l}\text { Between } \\
\text { Groups }\end{array}$ & 9.202 & 4 & 2.301 & 2.782 & .028 \\
\hline & Within Groups & 161.263 & 195 & .827 & & \\
\hline & Total & 170.465 & 199 & & & \\
\hline
\end{tabular}

Table 6 indicated that there is a significant difference among four barriers women face that prevent them from obtaining upper-level positions due to age (i.e. among internal business structural barriers, societal barriers, governmental barriers, and personal barriers); whereas no significant difference found for situational barriers due to the moderator variable of educational level.

Table 7. ANOVA analysis of barriers women face that prevent them from obtaining upper-level positions due to career level

\begin{tabular}{llrrrrr}
\hline & & \multicolumn{1}{c}{$\begin{array}{c}\text { Sum of } \\
\text { Squares }\end{array}$} & df & \multicolumn{1}{c}{$\begin{array}{c}\text { Mean } \\
\text { Square }\end{array}$} & F & Sig. \\
\hline IB & $\begin{array}{l}\text { Between } \\
\text { Groups }\end{array}$ & 7.742 & 3 & 2.581 & 2.434 & .066 \\
\cline { 2 - 8 } & Within Groups & 207.797 & 196 & 1.060 & & \\
\cline { 2 - 8 } & Total & 215.539 & 199 & & & \\
\hline SB & $\begin{array}{l}\text { Between } \\
\text { Groups }\end{array}$ & 6.000 & 3 & 2.000 & 4.066 & .008 \\
\cline { 2 - 8 } & Within Groups & 96.402 & 196 & .492 & & \\
\cline { 2 - 7 } & Total & 102.402 & 199 & & & \\
\hline
\end{tabular}




\begin{tabular}{llrrrrr}
\hline GB & $\begin{array}{l}\text { Between } \\
\text { Groups }\end{array}$ & 7.189 & 3 & 2.396 & 3.610 & .014 \\
\cline { 2 - 7 } & Within Groups & 130.116 & 196 & .664 & & \\
\cline { 2 - 7 } & Total & 137.305 & 199 & & & \\
\hline TB & $\begin{array}{l}\text { Between } \\
\text { Groups }\end{array}$ & 3.474 & 3 & 1.158 & 3.413 & .019 \\
\cline { 2 - 7 } & Within Groups & 66.486 & 196 & .339 & & \\
\cline { 2 - 7 } & Total & 69.959 & 199 & & & \\
\hline PB & Between & 3.784 & 3 & 1.261 & 1.483 & .220 \\
& Groups & 166.682 & 196 & .850 & & \\
\cline { 2 - 7 } & Within Groups & 170.465 & 199 & & & \\
\cline { 2 - 6 } & Total & & & & & \\
\hline
\end{tabular}

Table 7 showed that there is a significant difference among four barriers women face that prevent them from obtaining upper-level positions due to age (i.e. among internal business structural barriers, societal barriers, governmental barriers, and situational barriers); whereas no significant difference found for personal barriers due to the moderator variable of career level.

Table 8. ANOVA analysis of barriers women face that prevent them from obtaining upper-level positions due to work experience

\begin{tabular}{|c|c|c|c|c|c|c|}
\hline & & $\begin{array}{l}\text { Sum of } \\
\text { Squares }\end{array}$ & $\mathrm{df}$ & $\begin{array}{c}\text { Mean } \\
\text { Square }\end{array}$ & $\mathrm{F}$ & Sig. \\
\hline \multirow[t]{3}{*}{ IB } & $\begin{array}{l}\text { Between } \\
\text { Groups }\end{array}$ & 22.104 & 2 & 11.052 & 11.256 & .000 \\
\hline & Within Groups & 193.435 & 197 & .982 & & \\
\hline & Total & 215.539 & 199 & & & \\
\hline \multirow[t]{3}{*}{ SB } & $\begin{array}{l}\text { Between } \\
\text { Groups }\end{array}$ & 6.357 & 2 & 3.179 & 6.520 & .002 \\
\hline & Within Groups & 96.045 & 197 & .488 & & \\
\hline & Total & 102.402 & 199 & & & \\
\hline \multirow[t]{3}{*}{ GB } & $\begin{array}{l}\text { Between } \\
\text { Groups }\end{array}$ & 8.826 & 2 & 4.413 & 6.766 & .001 \\
\hline & Within Groups & 128.479 & 197 & .652 & & \\
\hline & Total & 137.305 & 199 & & & \\
\hline \multirow[t]{3}{*}{ TB } & $\begin{array}{l}\text { Between } \\
\text { Groups }\end{array}$ & 1.038 & 2 & .519 & 1.483 & .229 \\
\hline & Within Groups & 68.921 & 197 & .350 & & \\
\hline & Total & 69.959 & 199 & & & \\
\hline \multirow[t]{3}{*}{ PB } & $\begin{array}{l}\text { Between } \\
\text { Groups }\end{array}$ & 5.777 & 2 & 2.888 & 3.455 & .034 \\
\hline & Within Groups & 164.689 & 197 & .836 & & \\
\hline & Total & 170.465 & 199 & & & \\
\hline
\end{tabular}

Table 8 indicated that there is a significant difference among four barriers women face that prevent them from obtaining upper-level positions due to age (i.e. among internal business structural barriers, societal barriers, governmental barriers, and personal barriers); whereas no significant difference found for situational barriers due to the moderator variable of work experience. 


\section{Discussion and Conclusions}

This research study examined the impact of the glass ceiling in Jordanian organizations from the aspects of organizational practices, male culture and the impact of family and social commitments that prevent women to reach top positions. The results confirmed all the fourth hypotheses. The results showed that the glass ceiling is being reflected by the existence of male culture and organizational practices inside Jordanian organizations more than family and social commitments. In other words, women consider that the internal culture of the organization is generally not supportive to positive attitudes towards women such as promotion, selection and mentoring, So, the explanation for women have fewer opportunities comparing with men for the career progress at work, are anticipated discrimination from the existence of informal male networks and organizational policies, rather than lack of the ambition or self-confidence. Family obligations do not appear to be a great barrier for women career progress, because Jordanian female managers are capable to combine work and family. It is obvious that western countries provide facilities or at least do not build rigid glass ceiling that prevents women to reach top positions more than eastern countries. In Jordan women's employment gained its legitimacy through government amendments in labor laws, media encouragement for more liberal attitude towards women's working and national ceremonies sponsored by the royal family and government. The differences in attitudes towards women's employment frequently begin at the top positions.

In Jordan women's employment gained its legitimacy through government amendments in labor laws, media encouragement for more liberal attitude towards women's working and national ceremonies sponsored by the royal family and government. The differences in attitudes towards women's employment frequently begin at the top positions, where as male culture appears clearly among males who believe that they perform better than women in top positions; as a result, organizational practices will be affected by the decision maker who holds a male culture (Al-Manasra, 2013). The aim of this research was to investigate why few women have entered hotel senior management positions in Zimbabwe. Importantly, it also aimed to find whether there were significant gender differences in the perceptions of facilitators and obstacles to entry into hotel senior management in Zimbabwe. The study has confirmed differences in perceptions of some facilitators and obstacles to management positions between male and female managers. Some of the ways women are discriminated against include sexual discrimination, conflict between work and family, lack of equity in promotion and being able to relocate to other business units (Manwa, 2014).

In-depth research on women entrepreneurship is required. There is a need for more accurate data on women-led MSEs in order to assess realities and challenges they are faced with in Lebanon. It needs to be incorporated within national surveys such as the National Households Living Conditions Survey (prepared by the Central Administration for Statistics-CAS) and other indices of women economic empowerment compounded by various UN agencies (Hamdan et al., 2007). Some of the organizations and associations mentioned above were established as entrepreneurship support centers. Others are women's organizations aiming at defending and enhancing the rights of women. Almost all of these women's organizations have entered the field of entrepreneurship due to demands arising from women without any profession and with insufficient levels of education required for paid jobs. Most of these organizatons are located either in the earthquake region or in the Southeastern Turkey (Ozar, 2007).

Organization's diversity initiatives should encompass sponsorship, mentorship, networking, succession planning, and directorships. These initiatives should include a true work-life flexibility policy and be an inclusive part of the organization's strategy and culture, for every employee. Hospitality organizations could also enlarge strategy meetings to include emerging midlevel leaders, including 50\% women, and provide opportunities to collaborate about any issues regarding their diversity initiatives (Clevenger \& Singh, 2013). In order to achieve the aim of this study a direct question "do you believe that a glass ceiling exists in your organisation?" would have established whether the glass ceiling is a reality or a myth. However, the questions were posed in a manner that has identified barriers without asking a direct question. It is evident that certain elements of the situational/organisational theory of the glass ceiling existed (Kiaye \& Singh, 2013).

The dimensions of Jordanian women employees in the tourism sector that aimed to highlighting the nature of women participation in the tourism sector and the main positive aspects of the tourism employment in aim to the motivate women to contribute in increasing their participation in the tourism activities. The study concludes that women's participation is affected by the prevailing local tradition and customs, the social misperception of working women in tourism industry, the lack of family support and the low confidence of management in women as leaders. The study recommends establish legislation, performing awareness programs on the importance and rule of working women in the tourism sector, conducting training programs as per the needs of women and the opportunities available in the 
sector, in addition to offering incentives and facilities to working women in tourism (Ajlouni \& Murar, 2012).

The main limitation of this study was related to the difficulty of reaching women managers in mid-level positions. This study needs more comprehensive research in private and public sectors especially in Middle East countries, because attitudes toward women career progress in public sector in Middle East countries seems to be influenced by other factors such as "wasta". Wasta is an Arabic word which in English means nepotism (Shannak et al., 2012a). In the workplace, nepotism is defined as individuals showing favoritism to the family, members and friends by providing them with jobs or giving them promotions based on their relationships not on competence. Including the lack of studies on the role of women in the tourism sector, and the difficulty of the decision by the women to work in the field of tourism. The study recommends making and providing programs to qualify and aware women to work in tourism sector and all tourism aspects; involve women in social tourism development to reduce future barriers for women's work; confirmation for principle of equality and fair evaluation for women and provide opportunities to her as men; make seminars or training centers for women to aware her about tourism sector; and enable academic and scientific capabilities of women to be able to take over managerial positions in tourism.

In addition, women should consider jobs require Information Technology (IT) skills, and how could impact their decisions. Indeed, several researchers consider the information systems and in particular the IT and its flexibility as an enabler to achieve the desired competitive advantages, and as a crucial support to operational and strategic business decisions (Al Azmi et al., 2012; Alenezi et al., 2015; Alkalha et al., 2012; Almajali \& Tarhini, 2016; Altamony et al., 2012; Kateb et al., 2015; Maqableh \& Karajeh, 2014a, 2014b; Masa'deh, 2012, 2013a, 2013b; Masa'deh et al., 2016; Obeidat et al., 2013; Shannak et al., 2010, 2012b; Tarhini et al., 2016; Vratskikh et al., 2016); thus further research is required to examine the role of such IT applications in enhancing the managerial decisions. Also, scholars (e.g. Masa'deh et al. 2008; Hunaiti et al., 2009; Masa'deh \& Kuk, 2009; Alshurideh et al., 2012; Hajir et al., 2015; Kannan \& Gharibeh, 2013; Masa'deh \& Shannak, 2012; Masa'deh et al. 2013; Masa'deh et al. 2015a, 2015b, 2015c; Masa'deh et al. 2017; Obeidat et al., 2012, 2016; Shannak \& Alkour, 2012; Tarhini et al., 2015a, 2015b) emphasize the need for large firms to integrate their IT systems with their KM strategies and processes in order to survive in their highly competitive business environments, which in turn could accelerate the managerial decisions as well.

\section{References}

Abbasi, M. S., Elyas, T., \& Shah, F. (2015). Impact of individualism and collectivism over the individual's technology acceptance behaviour: A multi-group analysis between Pakistan and Turkey. Journal of Enterprise Information Management, 28(6), 747-768. https://doi.org/10.1108/JEIM-12-2014-0124

Ajlouni, F., \& Murar, S. (2012). Women and Work in Jordan Empowerment Programme: Case Study of Tourism. Master Thesis, Faculty of Business Middle East University, Jordan.

Al Azmi, N., Al-Lozi, M., Al-Zu'bi, Z., Dahiyat, S., \& Masa'deh, R. (2012). Patients Attitudes toward Service Quality and its Impact on their Satisfaction in Physical Therapy in KSA Hospitals. European Journal of Social Sciences, 34(2), 300-314.

Al Zoubi, R., \& Alkharoof, A. (2015). Young's Position on Women's Work in the Tourism Sector: A Case Study of Students at the University of Jordan. Journal of the Jordanian Islamic Science, 8(1).

Al-Badi, A., Tarhini, A., \& Al-Kaaf, W. (2017). Financial Incentives for Adopting Cloud Computing in Higher Educational Institutions. Asian Social Science, 13(4), 162-174. https://doi.org/10.5539/ass.v13n4p162

Al-Badi, A., Tarhini, A., \& Al-Sawaei, S. (2017). Utilizing Social Media to Encourage Domestic Tourism in Oman. International Journal of Business and Management, 12(4), 84-94. https://doi.org/10.5539/ijbm.v12n4p84

Al-Badi, A. H., \& Al-Qayoudhi, W. S. (2014). Adoption of social networks in business: Study of users and potential users in Oman. The International Business \& Economics Research Journal (Online), 13(2), 401-415. https://doi.org/10.19030/iber.v13i2.8457

Al-Dmour, R., \& Obeidat, B. (2015). Strategic IT-Business Alignment as Managers' Explorative and Ecploitative Strategies. European Scientific Journal, 11(7), 437-457

Al-Dmour, H., Al-Madani, S., Alansari, I., \& Al-Dmour, R. (2016). Factors Affecting the Effectiveness of Cause-Related Marketing Campaign: Moderating Effect of Sponsor-Cause Congruence. International Journal of Marketing Studies, 8(5), 114-127. https://doi.org/10.5539/ijms.v8n5p114

Alenezi, H., Masa'deh, R. Alalwan, A., \& Al-Qirim, N. (2017). Factors Affecting e-Government Adoption in Kuwait: A Qualitative study. Electronic Journal of e-Government, 15(2), 84-102. 
Alenezi, H., Tarhini, A., \& Masa'deh, R. (2015). Investigating the Strategic Relationship between Information Quality and E-Government Benefits: A Literature Review. International Review of Social Sciences and Humanities, 9(1), 33-50.

Alkalha, Z., Al-Zu'bi, Z., Al-Dmour, H., \& Alshurideh, M. (2012). Investigating the Effects of Human Resource Policies on Organizational Performance: An Empirical Study on Commercial Banks Operating in Jordan. European Journal of Economics, Finance and Administrative Sciences, 51, 44-64.

Allam, M., \& Elyas, T. (2016). Perceptions of Using Social Media as an ELT Tool among EFL Teachers in the Saudi Context. English Language Teaching, 9(7), 1-9. https://doi.org/10.5539/elt.v9n7p1

Almajali, D., \& Tarhini, A. (2016). Antecedents of ERP Systems Implementation Success: A Study on Jordanian Healthcare Sector. Journal of Enterprise Information Management, 29(4), 549-565.

Al-Manasra, A. (2013). What Are the "Glass Ceiling" Barriers Effects on Women Career Progress in Jordan. International Journal of Business and Management, 8(6), 22-37. https://doi.org/10.5539/ijbm.v8n6p40

Al-Mukhaini, E. M., Al-Qayoudhi, W. S., \& Al-Badi, A. H. (2014). Adoption of social networking in education: A study of the use of social networks by higher education students in Oman. Journal of International Education Research, 10(2), 143-155. https://doi.org/10.19030/jier.v10i2.8516

Al-Qirim, M., Rouibah, K., Serhani, M. A., Yammahi, A. R., \& Yammahi, M. A. (2017). Towards a Personality Understanding of Information Technology Students and their IT Learning in UAE University. Education and Information Technologies, 1-12. https://doi.org/10.1007/s10639-017-9578-1

Al-Qirim, N., Rouibah, K., Serhani, M. A., Yammahi, A. R., \& Yammahi, M. A. (2017). Learning Orientations of IT Higher Education Students in UAE University. Education and Information Technologies, 1-14. https://doi.org/10.1007/s10639-017-9589-y

Al-Qirim N., Tarhini, A., Rouibah, K. (2017). Determinants of Big Data Adoption and Success. In International Conference on Communications and Future Internet (ICCFI 2017). Jeju Island, South Korea, 10-13 August.

Alqahtani, M. A., Al-Badi, A. H., \& Mayhew, P. J. (2012). The Enablers and Disablers of E-Commerce: Consumers' Perspectives. The Electronic Journal of Information Systems in Developing Countries, 54(1), 1-25.

Alrowwad, A., Obeidat, B.Y., \& Aqqad, N. (2017). The impact of transformational leadership on organizational performance via the mediating role of corporate social responsibility: A structural equation modeling approach. International Business Research, 10(1), 199-221. https://doi.org/10.5539/ibr.v10n1p199

Alshurideh, M., Masa'deh, R., \& Alkurdi, B. (2012). The Effect of Customer Satisfaction on Customer Retention in the Jordanian Mobile Market: An Empirical Investigation. European Journal of Economics, Finance and Administrative Sciences, 47, 69-78.

Altamony, H., Alshurideh, M., \& Obeidat, B. (2012). Information Systems for Competitive Advantage: Implementation of an Organizational Strategic Management Process. Proceedings of the 18th IBIMA Conference on Innovation and Sustainable Economic Competitive Advantage: From Regional Development to World Economic, Istanbul, Turkey, 9th-10th May.

Altamony, H., Al-Salti, Z., Gharaibeh, A., \& Elyas, T. (2016). The relationship between Change Management Strategy and Successful Enterprise Resource Planning (ERP) Implementations: A Theoretical Perspective. International Journal of Business Management and Economic Research, 7(4), 690-703.

Badarin, R., \& Qawasmeh, F. (2012). Role of Women in Leading Change: Applied Study on Working Women Organizations in Jordan. Al-Balqa for Research and Studies, 16(1), 17-57.

Bagozzi, R., \& Yi, Y. (1988). On the Evaluation of Structural Evaluation Models. Journal of the Academy of Marketing Science, 16(1), 74-94.

Bisharat, H., Obeidat, B.Y., Alrowwad, A., Tarhini, A., \& Mukattash, I. (2017). The Effect of Human Resource Management Practices on Organizational Commitment in Chain Pharmacies in Jordan. International Journal of Business and Management, 12(1), 50-67. https://doi.org/10.5539/ijbm.v12n1p50

Brenton, P., Gamberoni, E., \& Sear, C. (2013). Women and trade in Africa: realizing the potential. World Bank, Washington, DC.

Clevenger, L., \& Singh, N. (2013). Exploring Barriers That Lead to the Glass Ceiling Effect for Women in the U.S. Hospitality Industry. Journal of Human Resources in Hospitality \& Tourism, 12, 376-399. 
Creswell, J. (2009). Research Design: Qualitative, Quantitative, and Mixed Methods Approaches (3rd ed.). Thousand Oaks: Sage Publications.

El-Masri, M., \& Tarhini, A. (2015). A Design Science Approach to Gamify Education: From Games to Platforms. Twenty-Third European Conference on Information Systems (ECIS), Münster, Germany. 26-29 May 2015.

El-Masri, M., \& Tarhini, A. (2017). Factors affecting the adoption of e-learning systems in Qatar and USA: Extending the Unified Theory of Acceptance and Use of Technology 2 (UTAUT2). Educational Technology Research and Development, 65(3), 743-763. https://doi.org/10.1007/s11423-016-9508-8

El-Masri, M., Orozco, J., Tarhini, A., \& Tarhini, T. (2015). The Impact of IS-Business Alignment Practices on Organizational Choice of IS-Business Alignment Strategies. The 19th Pacific Asia Conference on Information Systems (PACIS 2015), Paper 215, Singapore, 6-9 July 2015.

Elyas, T., \& Picard, P. (2012). Teaching and Moral Tradition in Saudi Arabia: A Paradigm of Struggle or Pathway towards Globalization?. Procedia - Social and Behavioral Sciences, 41, 1083-1086. https://doi.org/10.1016/j.sbspro.2012.06.782

Fedai, L., Dagl1, G., Altınay, Z., \& Altınay, F. (2017). The examination of occupational burnout and job satisfaction of the physical education teachers. International Journal of Economic Perspectives, 11(1), 12-26.

Hajir, J., Obeidat, B., \& Al-dalahmeh, M. (2015). The Role of Knowledge Management Infrastructure in Enhancing Innovation at Mobile Telecommunication Companies in Jordan. European Journal of Social Sciences, 50(3), 313-330.

Hamdan, K., \& Hamdan, R., and Batlouni, L., \& Mansour, N. (2007). Women Entrepreneurs in the MENA Region: Obstacles, Potentials \& Future Prospects: The case of Lebanon. Business \& Economics.

Hamoud, M., Akour, M. A., \& Al-Salti, Z. (2016). Developing the Main Knowledge Management Process via Social Media in the IT Organisations: A Conceptual Perspective. International Journal of Business Administration, 7(5), 49-64.

Hassouna, M., Elyas, T., \& Abou Trab, M. S. (2015). Customer Churn in Mobile Markets: A Comparison of Techniques. International Business Research, 8(6), 224-237. https://doi.org/10.5539/ibr.v8n6p224

Hussian, A., Elyas, T., \& Nasseef, O. (2013). Research Paradigms: A Slippery Slope for Fresh Researchers. Life Science Journal, 10(4), 2374-2381.

Hunaiti, Z., Mansour, M., \& Al-Nawafleh, A. (2009). Electronic Commerce Adoption Barriers in Small and Medium-Sized Enterprises (SMEs) in Developing Countries: The Case of Libya. IBIMA Business Review, 2(5), 37-45.

Hutchings, K., Dawn Metcalfe, B., \& Cooper, B. K. (2010). Exploring Arab Middle Eastern Women's Perceptions of Barriers to, and Facilitators of, International Management Opportunities. The International Journal of Human Resource Management, 21(1), 61-83. https://doi.org/10.1080/09585190903466863

Kanaan, R., \& Gharibeh, A. (2013). The Impact of Knowledge Sharing Enablers on Knowledge Sharing Capability: An Empirical Study on Jordanian Telecommunication Firms. European Scientific Journal, 9(22), 237-258.

Kateb, M., Swies, R., Obeidat, B., \& Maqableh, M. (2015). An Investigation on the Critical Factors of Information System Implementation in Jordanian Information Technology Companies. European Journal of Business and Management, 7(36), 11-28.

Kiaye, R., \& Singh, A. (2013). The Glass Ceiling: A Perspective of Women Working in Durban. Gender in Management: An International Journal, 28(1), 28-42. https://doi.org/10.1108/17542411311301556

Mahadeen, B., Al-Dmour, R., \& Obeidat, B. Y. (2016). Examining the effect of the Organization's Internal Control System on Organizational Effectiveness: A Jordanian empirical study. International Journal of Business Administration, 7(6), 22-41. https://doi.org/10.5430/ijba.v7n6p22

Majcher-Teleon, A., \& Slimène, O. B. (2009). Women and Work in Jordan. Case study of Tourism and ICT Sectors. Working Paper, European Training Foundation, 1-36.

Manwa, H.A. (2014). Gender Gap in Management Positions: A Survey of Male and Female Managers in Zimbabwean Hotels. Gender and Behaviour, 12(3), 5936-5945.

Maqableh, M., \& Karajeh, H. (2014a). Job Scheduling for Cloud Computing Using Neural Networks. Communications and Network, 6(3), 191. https://doi.org/10.4236/cn.2014.63021 
Maqableh, M., \& Karajeh, H. (2014b). A Theoretical Perspective on the Relationship between Leadership Development, Knowledge Management Capability, and Firm Performance. Asian Social Science, 10(6), 128.

Masa'deh, R. (2013). The Impact of Information Technology Infrastructure Flexibility on Firm Performance: An Empirical Study of Jordanian Public Shareholding Firms. Jordan Journal of Business Administration, 204-224.

Masa'deh, R., \& Kuk, G. (2009). Antecedents and Intermediaries between Strategic Alignment and Firm Performance. Conference of the Academy of Management Annual Meeting (AOM), Illinois, Chicago, USA.

Masa'deh, R., Gharaibeh, A., Maqableh, M., \& Karajeh, H. (2013a). An Empirical Study of Antecedents and Outcomes of Knowledge Sharing Capability in Jordanian Telecommunication Firms: A Structural Equation Modeling Approach. Life Science Journal, 10(4), 2284-2296.

Masa'deh, R., Hunaiti, Z., \& Bani Yaseen, A. (2008). An Integrative Model Linking IT-Business Strategic Alignment and Firm Performance: The Mediating Role of Pursuing Innovation and Knowledge Management Strategies. Communications of the International Business Information Management Association (IBIMA) Journal, 2(24), 180-187.

Masa'deh, R., Shannak, R., \& Maqableh, M. (2013b). A Structural Equation Modeling Approach for Determining Antecedents and Outcomes of Students' Attitude toward Mobile Commerce Adoption. Life Science Journal, $10(4), 2321-2333$.

Masa'deh, R., Tayeh, M., Al-Jarrah, I., \& Tarhini, A. (2015c). Accounting vs. Market-based Measures of Firm Performance Related to Information Technology Investments. International Review of Social Sciences and Humanities, 129-145.

Masa'deh, R. (2012). The Impact of Management Information Systems (MIS) on Quality Assurance (QA): A Case Study in Jordan. International Journal of Information, Business, and Management, 93-110.

Masa'deh, R., \& Shannak, R. (2012). Intermediary Effects of Knowledge Management Strategy and Learning Orientation on Strategic Alignment and Firm Performance. Research Journal of International Studies, 112-128.

Masa'deh, R., Gharaibeh, A., Tarhini, A., \& Obeidat, O. (2015a). Knowledge Sharing Capability: A Literature Review. In Fourth Scientific \& Research Conference on New Trends in Business, Management and Social Sciences, Istanbul, Turkey, 19-20 September 2015 (pp. 1-16). https://doi.org/10.2139/ssrn.2696924

Masa'deh, R., Obeidat, B., \& Tarhini, A. (2016). A Jordanian Empirical Study of the Associations among Transformational Leadership, Transactional Leadership, Knowledge Sharing, Job Performance, and Firm Performance: A Structural Equation Modelling Approach. Journal of Management Development, 35(5), 681-705. https://doi.org/10.1108/JMD-09-2015-0134

Masa'deh, R., Obeidat, B., Al-Dmour, R., \& Tarhini, A. (2015b). Knowledge Management Strategies as Intermediary Variables between IT-Business Strategic Alignment and Firm Performance. European Scientific Journal, 11(7), 344-368.

Masa'deh, R., Shannak, R., Maqableh, M., \& Tarhini, A. (2017). The Impact of Knowledge Management on Job Performance in Higher Education: The Case of the University of Jordan. Journal of Enterprise Information Management, 30(2), 244-262. https://doi.org/10.1108/JEIM-09-2015-0087

Nassar, B., \& Arzoky, M. (2015). An Empirical Analysis of the Seasonal Patterns in Aggregate Directors' Trades. International Journal of Economics and Finance, 7(9), 59-84. https://doi.org/10.5539/ijef.v7n9p59

Obeidat, B. Y., Hashem, L., Alansari, I, \& Al-Salti, Z. (2016). The Effect of Knowledge Management Uses on Total Quality Management Practices: A Theoretical Perspective. Journal of Management and Strategy, 7(4), 18-29.

Obeidat, B., Al-Suradi, M., \& Tarhini, A. (2016). The Impact of Knowledge Management on Innovation: An Empirical Study on Jordanian Consultancy Firms. Management Research Review, 39(10), 1214-1238.

Obeidat, B., El-Rimawi, S., Maqableh, M., \& Al-Jarrah, I. (2013). Evaluating the Profitability of the Islamic Banks in Jordan. European Journal of Economics, Finance and Administrative Sciences, 56, 27-36.

Obeidat, B., Sweis, R., Zyod, D., \& Alshurideh, M. (2012). The Effect of Perceived Service Quality on Customer Loyalty in Internet Service Providers in Jordan. Journal of Management Research, 4(4), 224-242.

Obeidat, B.Y., Al-Sarayrah, S., Al-Salti, Z., \& Sweis, R. (2016). Cultural Influence on Strategic Human Resource Management Practices: A Jordanian case study. International Business Research, 9(10), 94-114. https://doi.org/10.5539/ibr.v9n10p94 
Obeidat, B.Y., Tarhini, A., \& Aqqad, N. (2017). The impact of intellectual capital on innovation via the mediating role of knowledge management: A structural equation modeling approach. International Journal of Knowledge Management Studies, 8(2), 15-33.

Orozco, J., Tarhini, A., Masa'deh, R., \& Tarhini, T. (2015). A framework of IS/business alignment management practices to improve the design of IT Governance architectures. International Journal of Business and Management, 10(4), 1-12. https://doi.org/10.5539/ijbm.v10n4p1

Ozar, S. (2007). Women Entrepreneurs in Turkey Obstacles, Potentials and Future Prospects. Working Paper, Faculty of Economics and Administrative Sciences, Yasar University, Turkey, 1-77.

Pallant, J. (2005). SPSS Survival Manual: A Step Guide to Data Analysis Using SPSS for Windows Version 12. Chicago, Illinois: Open University Press.

Pollard, P. L. (2007). A Critical Analysis of Gender-based Workplace Challenges Facing Women: Gender and Compensation. Forum on Public Policy: A Journal of the Oxford Round Table.

Sekaran, U., \& Bougie, R. (2013). Research Methods for Business: A Skill-Building Approach (6th ed.). New York: Wiley.

Shannak, R., \& Akour, M. (2012). Knowledge Management Strategy Building: Literature Review. European Scientific Journal, 8(15), 143-168.

Shannak, R., Al-Zu'bi, Z., Alshurideh, M., \& Altamony, H. (2012b). A Theoretical Perspective on the Relationship between Knowledge Management Systems, Customer Knowledge Management, and Firm Competitive Advantage. European Journal of Social Sciences, 32(4), 520-532.

Shannak, R., Obeidat, B., \& Almajali, D. (2010). Information Technology Investments: A Literature Review. Proceedings of the 14th IBIMA Conference on Global Business Transformation through Innovation and Knowledge Management: An Academic Perspective, Istanbul-Turkey, 23rd-24th June, pp.1356-1368.

Shannak, R., Obeidat, B., \& Masa'deh, R. (2012a). Culture and the Implementation Process of Strategic Decisions in Jordan. Journal of Management Research, 4(4), 257-281. https://doi.org/10.5296/jmr.v4i4.2160

Storvik, A. E., \& Schone, P. (2008). In Search of the Glass Ceiling: Gender and Recruitment to Management in Norway's State Bureaucracy. The British Journal of Sociology, 59(4), 729-755.

Tarhini, A., Al-Badi, A., Almajali, M., \& Alrabayaah, S. H. (2017). Factors influencing employees' Intention to use Cloud Computing. Journal of Management \& Strategy, 8(2), 47-62. https://doi.org/10.5430/jms.v8n2p47

Tarhini, A., Elyas, T., Akour, M. A., \& Al-Salti, Z. (2016). Technology, Demographic Characteristics and E-Learning Acceptance: A Conceptual Model Based on Extended Technology Acceptance Model. Higher Education Studies, 6(3), 72-89. https://doi.org/10.5539/hes.v6n3p72

Tarhini, A., El-Masri, M., Ali, M., \& Serrano, A. (2016). Extending the UTAUT model to understand the customers' acceptance and use of internet banking in Lebanon: A structural equation modeling approach. Information Technology and People, 29(4), 830-849. https://doi.org/10.1108/ITP-02-2014-0034

Tarhini, A., Arachchilage, N., \& Abbasi, M. (2015). A Critical Review of Theories and Models of Technology Adoption and Acceptance in Information System Research. International Journal of Technology Diffusion, 6(4), 58-77. https://doi.org/10.4018/IJTD.2015100104

Tarhini, A., Mgbemena, C., AbouTrab, M.S., \& Masa'deh, R. (2015). User Adoption of Online Banking in Nigeria: A Qualitative study. Journal of Internet Banking and Commerce, 20(3), 1-8.

Tarhini, A., Mohammed, A., \& Maqableh, M. (2016). Modeling Factors Affecting Student's Usage Behaviour of E-Learning Systems in Lebanon. International Journal of Business and Management, 11(2), 299-314. https://doi.org/10.5539/ijbm.v11n2p299

Tohmé, A. (2001). Women, Intangible Heritage and Development in the Arab World. United Nations Educational, Scientific and Cultural Organization, 1-32.

Vratskikh, I., Al-Lozi, M., \& Maqableh, M. (2016). The Impact of Emotional Intelligence on Job Performance via the Mediating Role of Job Satisfaction. International Journal of Business and Management, 69-91. https://doi.org/10.5539/ijbm.v11n2p69 